\section{Relationship of the Sweetpotato Whitefly to a New Tomato Fruit Disorder in Florida}

\author{
D.J. Schuster ${ }^{1}$ \\ University of Florida, IFAS, Gulf Coast Research and Education Center, \\ Bradenron, FL 34203
}

T.F. Mueller

CMC Farms, P.O. Box 400, Immokalee, FL 33934

\author{
J.B. Kring ${ }^{2}$ and J.F. Price ${ }^{3}$ \\ University of Florida, IFAS, Gulf Coast Research and Education Center, \\ Bradenton, FL 34203
}

Additional index words. Bemisia tabaci, pest management, chemical control, Lycopersicon esculentum, irregular ripening, permethrin, endosulfan, insecticidal soap, sulfotepp

\begin{abstract}
A new disorder of fruit has been observed on tomato (Lycopersicon esculentum Mill.) in Florida. The disorder, termed irregular ripening, was associated with field populations of the sweetpotato whitefly, Bemisia tabaci (Gennadius) and is characterized by incomplete ripening of longitudinal sections of fruit. An increase in internal white tissue also was associated with whitefly populations. In field cage studies, fruit on tomato plants not infested with the sweetpotato whitefly exhibited slight or no irregular ripening, whereas fruit from infested plants did. Fruit from plants on which a whitefly infestation had been controlled before the appearance of external symptoms exhibited reduced symptoms compared to fruit from plants on which an infestation was uncontrolled.
\end{abstract}

A new disorder of tomato was observed in southwest Florida in late 1987 and became widespread in south Florida in Spring 1988 (Maynard and Cantliffe, 1989) and in west central Florida in Spring 1989. The disorder,

Received for publication 8 Jan. 1990. Florida Agricultural Experiment Stations Journal Series no. R-00376. Commercial products are mentioned in this publication solely for the purpose of providing specific information. Mention of a product does not constitute a guarantee or warranty of the products by the Agricultural Experiment Station or an endorsement over products not mentioned. This publication also reports research involving pesticides. It does not contain recommendations for their use, nor does it imply that the uses discussed here have been registered. All uses of pesticides must be registered by appropriate stare and federal agencies before they can be recommended. The cost of publishing this paper was defrayed in part by the payment of page charges. Under postal regulations. this paper therefore must be hereby marked advertisement solely to indicate this fact.

${ }^{1}$ Professor.

${ }^{2}$ Adjunct Professor.

${ }^{3}$ Associate Professor. termed irregular ripening, was characterized by inhibited or incomplete ripening of longitudinal sections of fruit (Fig. 1). Also associated with the disorder was an increase in internal white tissue that occurs in some cultivars being grown commercially in Florida. No foliar symptoms have been associated with irregular ripening.

Large populations of the sweetpotato whitefly preceded the appearance of irregular ripening. This insect had been reported guero, 1987) but had not been considered a pest in the state until 1986 when large populations infested poinsettia (Price, 1987). The insect was detected, but sparsely, in all tomato growing areas in the state by Fall 1987 (Schuster et al., 1989). The development of high populations in southwest Florida in late 1987, in south Florida in 1988, and in west central Florida in 1989 coincided with the appearance of irregular ripening.

The purpose of these investigations was to study the relationship between the sweetpotato whitefly and irregular ripening of tomato in the field. in Florida as early as 1900 (Hamon and Sal-
One experiment was conducted at the Southwest Florida Research and Education Center, Immokalee (Summer to Fall 1988) and two were conducted at the Gulf Coast Research and Education Center, Bradenton (Winter 1985-89 and Spring 1989). All experiments were conducted using cultural practices common to commercial tomato production in Florida including raised beds, fumigated soil, banded fertilizer, polyethylene mulch, and staked plants.

Four whitefly-free transplants of 'Solar Set' (Immokalee) or two transplants of 'Sunny' (Bradenton) were set inside $1.8 \times 1.8 \times$ $1.8 \mathrm{~m}$ cages of 64 -mesh lumite screen (BioQuip Products, Gardena, Calif.). Uninfested controls were maintained by applying insecticides every 3 to 7 days. Insecticides applied included permethrin (Ambush 2EC, 2.5 or $50 \mathrm{ml} / 100$ liter), endosulfan (Thiodan 50WP, $120 \mathrm{~g} / 100$ liter), oxamyl (Vydate 2L. $500 \mathrm{ml} / 100$ liter), or a combination of permethrin with potassium salt of fatty acids (Safer Insecticidal Concentrate, 2 liter/100 liter). Mancozeb (Dithane M-45, 180 to 240 $\mathrm{g} / 100$ liter) combined with copper (Tribasic Copper Sulfate, 240 to $480 \mathrm{gm} / 100$ liter) was applied every 3 to 7 days to all plants for preventive control of fungal and bacterial plant pathogens.

In the Summer 1988 trial, plants were set mid-July in nine field cages. On 1.5 Aug., plants in three randomly selected cages were infested with $\approx 150$ sweetpotato whitefly adults collected from infested, field-grown tomato plants. Three other randomly selected cages were infested with 200 whitefly adults from a laboratory colony maintained on poinsettia for about a year. No attempt was made to control the infestations once they had been initiated. The remaining three cages were left uninfested.

In the winter trial, plants were set midOctober in eight field cages. Plants in six randomly selected cages were infested twice, two weeks apart, with $\approx 200$ sweetpotato whitefly adults collected from infested, fieldgrown tomatoes. Three of the infested cages were covered with polyethylene film and fumigated twice in mid-January with sulfotepp insecticidal smoke (Plantfume 103, 0.35 $\left.\mathrm{g} \cdot \mathrm{m}^{-3}\right)$. Immature fruit that did not exhibit symptoms of irregular ripening were present. Plants in these cages were then treated according to the insecticidal schedule of the uninfested cages. No attempt was made to control the whiteflies in the remaining three infested cages.

In the Spring 1989 trial, plants were set 7 Mar. in nine field cages. Plants in six randomly selected cages were infested on 20 


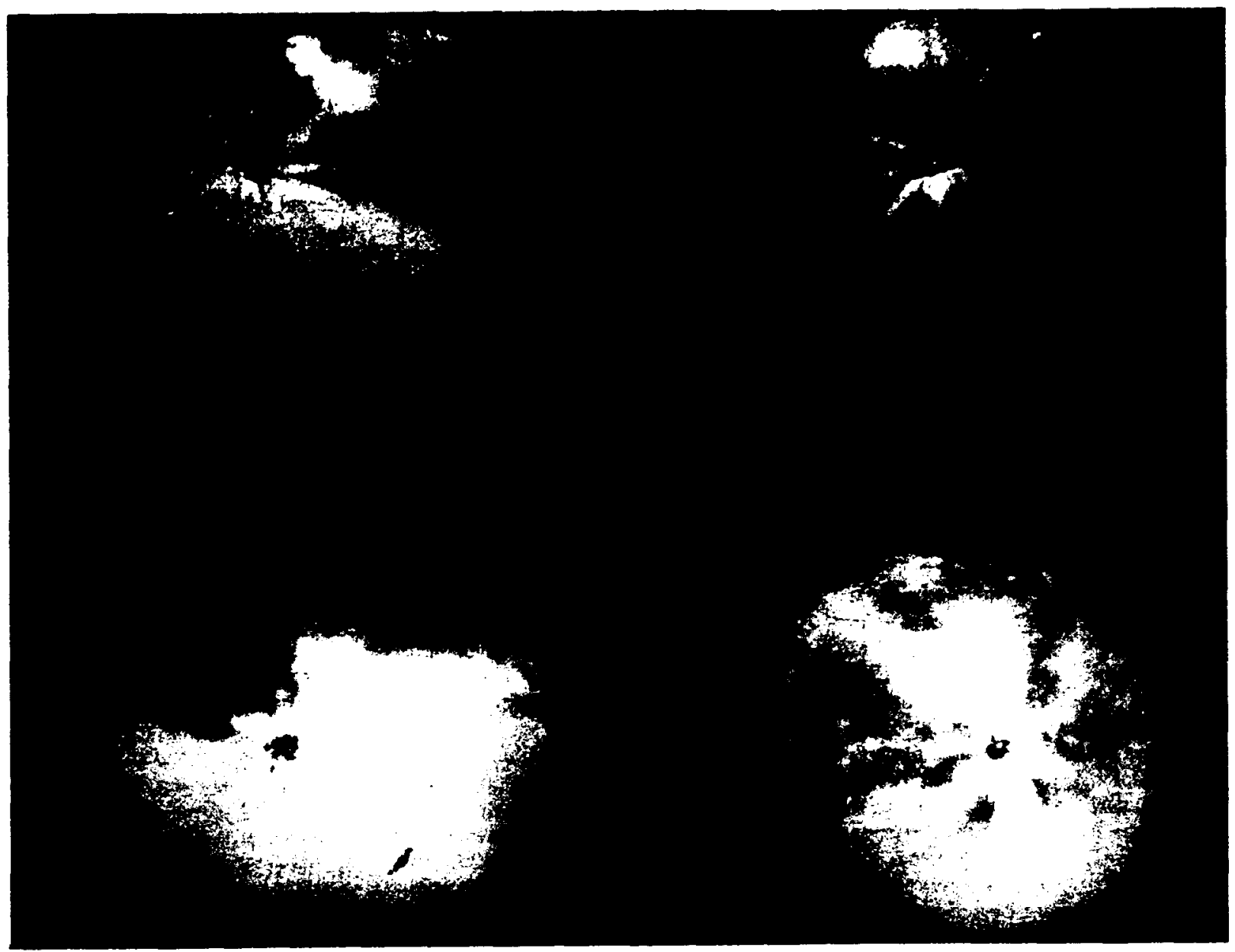

Fig. 1. Tomato fruit with irregular ripening associated with sweetpotato whitefly infestation.

and 28 Mar., 12 and 19 Apr. with $\approx 250$ whitefly adults collected from a laboratory colony maintained continuously for $\approx 1.5$ year on poinsettia. Beginning 11 May, three of the infested cages were selected randomly and were included in the whitefly control program of the uninfested cages. Immature but symptomless fruit were present. No attempt was made to control the whiteflies in the remaining three infested cages.

Beginning 23 Aug. at Immokalee, each cage was sampled weekly for immature whiteflies. The terminal leaflets from the seventh to 12th true leaf (counting down from the top of each of five stems per cage) were collected. The numbers of nymphs and pupae were counted under $15 \times$ magnification on a 2 -cm-diameter disk cut from the center of each leaflet.

At Bradenton, 10 leaves were selected randomly each week from the middle third of the plants in each cage. One (Winter 198889 ) or two $15-\mathrm{mm}$ leaf disks were cut from the terminal leaflet of each leaf and the number of eggs, crawlers, sessile nymphs, pupae, and pupae exuviae of the sweetpotato whitefly were counted and totaled.

Red ripe fruit were harvested and either rated for presence of external symptoms of irregular ripening (Immokalee) or rated 1 to 4 for increasing severity of symptoms (Bradenton). Fruit rated 2 had a faint star-like

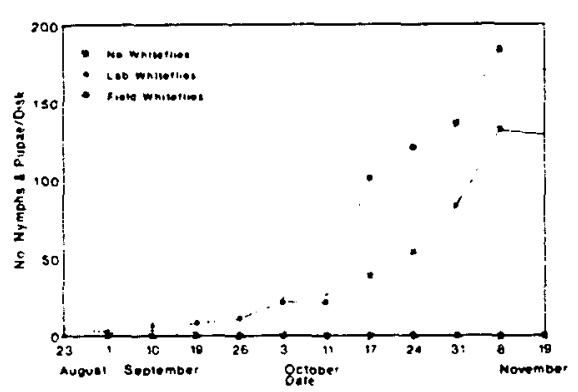

Fig. 2. Combined number of nymphs and pupae of the sweetpotato whitefly counted on leaf disks collected weekly from tomato plants in field cages either nor purposely infested with the whitefly or infested with either laboratory-reared or fieldcollected adults (Summer 1988).

pattern on the blossom end. Fruit rated 3 and 4 had $\leq 30 \%$ and $>30 \%$, respectively, of the fruit surface showing symptoms. Initially, the faint star was thought to be associated with irregular ripening. However, after evaluating many fruits, this symptom did not appear related to the disorder and was apparent whether whiteflies were present or not. A more distinct, golden star, in which the points of the star extended longitudinally, was associated with the disorder and automatically

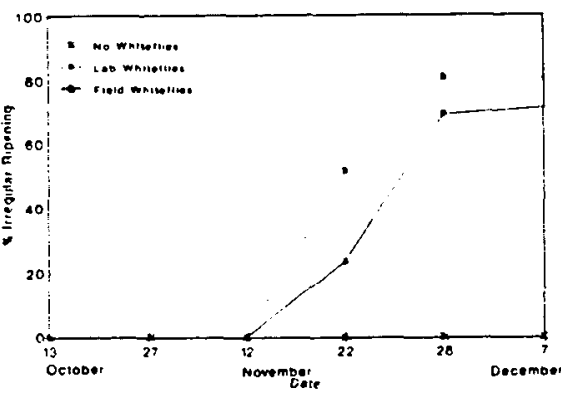

Fig. 3. Percentage of fruit exhibiting external symptoms of irregular ripening. Fruit were harvested from tomato plants in field cages either not purposely infested with the sweetpotato whitefly or infested with either laboratory-reared or field-collected whitefly adults (Summer 1988).

resulted in a rating of 3 . In the Immokalee trial and the spring trial at Bradenton, each fruit was cut transversely and rated 1 to 5 for increasing severity of internal white tissue.

At Immokalee, densities of sweetpotato whitefly nymphs and pupae were greatest in cages infested with laboratory-reared whiteflies (Fig. 2). The sweetpotato whitefly penetrated one of the cages not intentionally infested. However, the density in this cage 


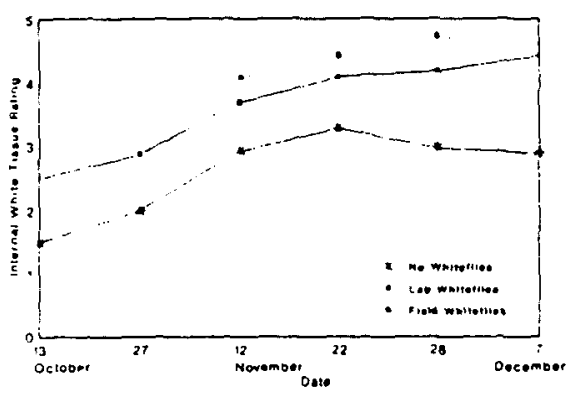

Fig. 4. Average rating (on a scale of 1 to 5 for increasing severity) of internal white tissue of fruit harvested from tomato plants in field cages either not purposely infested with the sweetpotato whitetly or infested with either laboratory-rearcd or field-colected whitefly adults (Summer 1988).
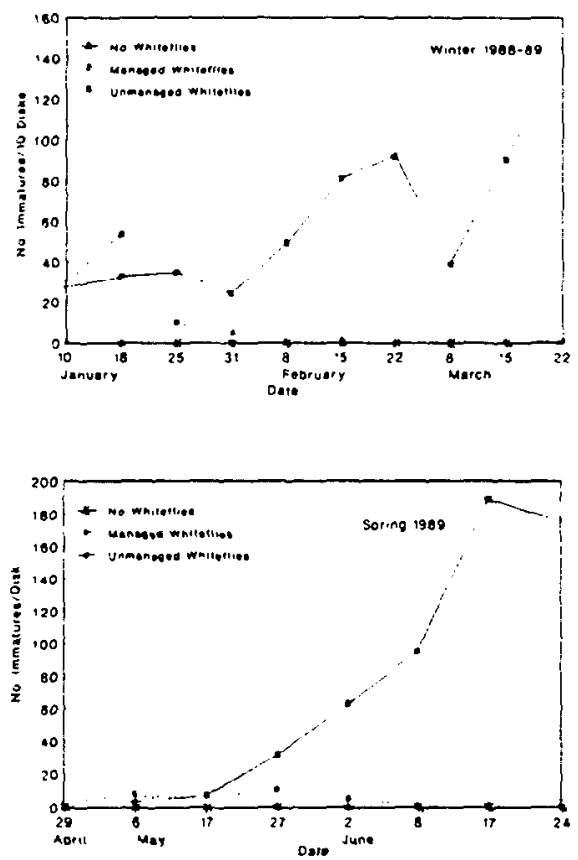

Fig. 5. Combined number of eggs, crawlers, sessile nymphs, and pupal exuviae of the sweetpotato whitefly counted on leaf disks collected from tomato plants during two seasons in field cages either not purposely infested with the sweetpotato whitefly or in field cages infested with whitefly adults and either controlled with insecticides or not controlled with insecticides. Note that vertical scales differ by a factor of 10 .

was less than the densities in the intentionally infested cages. A greater percentage of fruit in cages infested with the laboratoryreared whiteflies showed symptoms compared to fruit in cages infested with fieldcollected whiteflies (Fig. 3). No external symptoms were evident on fruit from the cages not intentionally infested. Internal white tissue was present in fruit from all cages regardless of whether whiteflies were introduced, although more white tissue was present in fruit harvested from plants in infested cages than in uninfested cages (Fig. 4).

At Bradenton, densities of sweetpotato
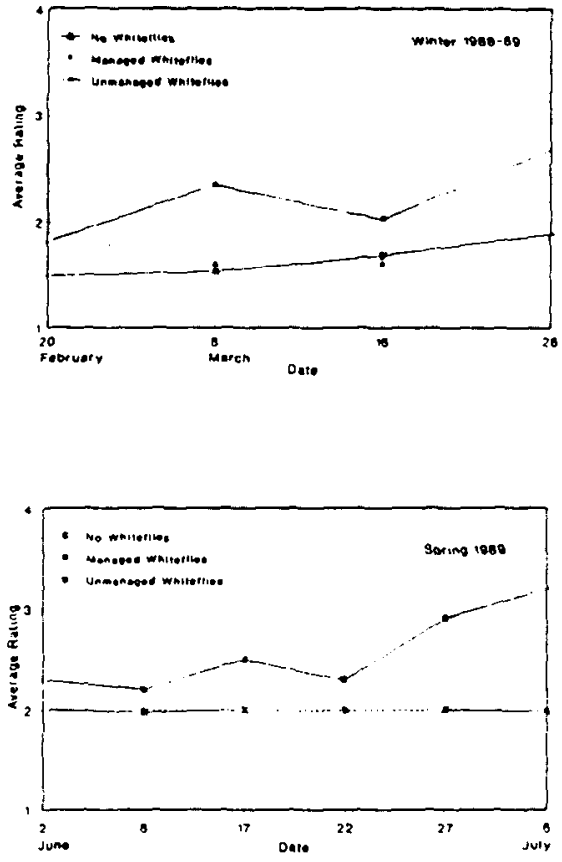

Fig. 6. Average rating (on a scale of 1 to 4 for increasing severity) of external symptoms of irregular ripening harvested from tomato plants in field cages either nor purposely infested with the sweetpotato whitefly or in field cages infested with whitefly adults and either controlled with insecticides or nor controlled with insecticides.

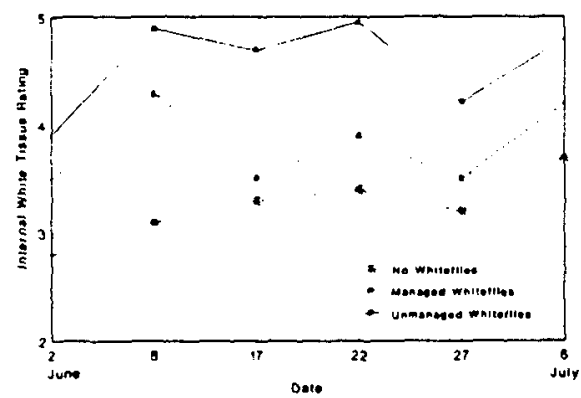

Fig. 7. Average rating (on a scale of 1 to 5 for increasing severity) of internal white tissue of fruit harvested from tomato plants in field cages either not purposely infested with the sweetpotato whitefly or in field cages infested with whitefly adults and either controlled with insecticides or not controlled with insecticides (Spring 1989).

whitefly immature lifestages (eggs, crawlers, sessile nymphs, and pupae) were greater in the spring trial than in the winter trial (Fig. 5). Densities in the infested (uncontrolled whiteflies) cages continued to increase throughout the trials. Few or no immatures were noted on leaf disks from the uninfested cages. Although the sweetpotato whitefly was not eliminated from those cages in which an attempt was made to control them, they were much less numerous than in the infested cages.

As with the densities of sweetpotato whitefly immature lifestages, the severity of irregular ripening symptoms was greater in the spring than in the winter trial (Fig. 6).
In uninfested cages in the winter trial, only two fruit out of a total of 354 harvested were rated 3 for external ripening. Both fruit were harvested from plants in a cage that inadvertently had become infested at a low level with the sweetpotato whitefly. No fruit in uninfested cages in the spring trial exhibited external symptoms of irregular ripening. The season average of Irregular ripening symptoms was greater for fruit from infested cages than for fruit from uninfested or whiteflycontrolled cages. Average ratings and estimates of marketability (fruit rated 3 or 4 ) of fruit from whitefly-controlled cages were not different from those of fruit from uninfested cages.

In general, symptoms of irregular ripening increased in infested cages as the season progressed in both trials (Fig. 6). In those cages in which an attempt was made to control the sweetpotato whitefly, the severity of symptoms tended to decline initially but later increased. In the winter trial, this increase corresponded to an increase in uninfested cages but remained below a rating of 2 . In the spring trial, this increase in whitefly-controlled cages exceeded a rating of 2 and approached the rating in infested cages on one harvest date.

In the spring trial, the rating of internal white tissue of fruit from infested cages was greater than that from uninfested cages (Fig. 7). Severity ratings of fruit from all infestation levels increased as the season progressed. A maximum rating of 5 was reached on the fourth harvest in infested cages but was never reached in either uninfested cages or in whitefly-controlled cages. Ratings in these latter cages approached those in infested cages by the last harvest.

In summary, these results link the irregular ripening disorder of tomato with the sweetpotato whitefly. The symptoms were apparent on fruit from infested plants regardless of the source of the whiteflies. The severity of expression of the disorder appeared related to the density of the sweetpotato whitefly since it could be reduced by reducing densities of the insect. Schuster et al. (1989) also found that, by using various insecticidal treatments under commercial field conditions, both densities of the whitefly and severity of irregular ripening symptoms were reduced.

\section{Literature Cited}

Hamon, A.B. and V. Salguero. 1987. Bemisia tabaci, sweetpotato whitefly, in Florida (Homoptera: Aleyrodidae: Aleyrodinae). Fla. Dept. Agr. and Consumer Serv. Div. of Plant Ind. Entomol. Circ. 292.

Maynard, D.N. and D.J. Cantliffe. 1989. Squash silverleaf and tomato irregular ripening: new vegetable disorders in Florida. Fla. Coop. Ext. Serv., IFAS, Univ. of Fla., Veg. Crops Fact Sheet VC-37.

Price, J.F. 1987. Controlling a new pest. Greenhouse Grower 5:70, 72-73.

Schuster, D.J., P.H. Everett, J.F. Price, and J.B Kring. 1989. Suppression of the sweetpotato whitefly on commercial fresh market tomatoes. Proc. Fla. State Hort. Soc. 102:374-379. 